\title{
Nollywood and the Leaders of Tomorrow: Interrogating Film Content and Character Formation of the Nigerian Child
}

\author{
Nkemakonam Aniukwu \\ http://dx.doi./org/10.4314/ujah.v20i3.4
}

\section{Abstract}

The intellectual discourse on the influence of films in shaping a child's ideological leaning is a topic that has generated interest in different parts of the world. The supposed proposition that inapt behaviours, nonchalant attitudes, moral decadence, and violence among children are outcome in most films produced in Nollywood Film Industry calls for serious examination. Hence, to examine the effects which film contents could have on educational development and character formation of a Nigerian child remains the aim of this study. Objectives include; to ascertain the potentials of films content in creating a standard for good leadership skills for the Nigerian child, and to advocate possible ways through which Nollywood movies can be produced to achieve all round development of the Nigerian child. The study through the adoption of observation, and content analysis approaches of qualitative research method, evaluated the influence of films on children. The study utilized George Gerbner's Cultivation theory in examining the influence of film environments in child's learning and leadership skill and found out that most Nollywood films have themes of Mischief, adult chauvinisms, hatred, demonic possessions, and violent politicking, among other social vices which pose serious threats to the child's ideal leadership purview. The researcher therefore recommends, establishment of a film unit that should provide adequate censorship of children films. The unit should be empowered to sieve, dissect and scrutinize all children 
film contents in Nollywood Film Industry so as to make sure that the filmmakers produce films relevance to the academic and character formation needs of Nigerian children. Hence, children are the leaders of tomorrow.

\section{Introduction}

A child is a human being between the age of birth and puberty. United Nation's Convention on the Right of the Child Article 1, defines a child as a "Person below the age of 18" (1). The study focuses on the children within Jean Piaget's Concrete Operational Stage of Cognitive Development. At this stage of development children begin to think more logically, but their thinking can also be very rigid.

Children in many societies are seen as the leaders of tomorrow and if this is true, how the society treats the affairs of this group of individuals is of paramount importance. The period of childhood plays a significant role in adolescent and in adulthood. During the first decade of life, the child experiences many encounters and interactions with his environment and these include the child's first contact with people and events which, overtime, come to influence the development of attitudes, emotions and behaviours of such a child. Canice Nwosu observes that" The child is the future of the nation, the bedrock of a nation's potential growth; therefore, his/her rights, survival and proper development must be adequately guaranteed by the wind of change" (48). Therefore, childhood in turn offers society its most promising opportunity to instruct and foster those human attributes most vital to its continued functioning and existence, and thus, the future of children and their importance to a society can only be fruitfully realized when the society understands how children develop, 
paying attention closely to their developmental stages and the learning materials available for their character formation.

The world of children has changed dramatically especially in Africa, for instance, in most homes in Nigeria today, it could be said that most children in the cities socialize more with their peers only in school and after school hours, they go home, move into their flat, to meet the absence of their parents who are still at their work places, most often they stay with a nanny, or a house help that is, if they have one, who would from time to time put on the television or film for the children regardless of the programmes' contents under display, most of the films/programmes children see on the television nowadays are questionable in terms of contents. Gone are the days when children play with their neighbours at home. The African structure of moonlight story telling tradition which offered children the avenue to socialize with other children and learn from their elders has gone into extinction in most Nigerian cities. Nwosu, discussing "The Changing Nigerian Family and the Rights of the Child..." once more posits that:

The family used to be the provider of informal education and primary educator of the child... unfortunately, the role of the family as agent of socialization has declined. In the pre-colonial Nigerian society, the family had the primary role of socializing the child. Contrarily, in the contemporary society, day-care centres, schools, peer groups, video bars, recreational parks and cinema houses have taken this role. The outcome is that the family has exposed the child to all sorts of danger and immorality. (36)

The above opinion buttresses the fact that things have really fallen apart when it comes to informal education of the Nigerian child. 
He goes further to note that "Materialism wealth acquisition and the desire to earn more income have also affected the commitments of parents to proper upbringing of the child." (36) Ameh Akoh sees the above negligence from the computer age and avers that:

...with the invasion of the computer into the living rooms and the concept of globalization, makes it imperative to evaluate the place of the African oral art in contemporary society. To some, the death of the oral art has long been celebrated. (110)

Furthermore, Ruth Finnegan notes that: "Oral literature is by definition dependent on a performer who formulates it in words on a specific occasion" (5) In order words, the performer who formulates the story to tell the children is well-grounded on the affairs of the children and would often times create intelligent stories that would help the children know more about their cultures, and leadership skills as often the case in the society. Such storytellers are seldom found in Nollywood Film Industry.

\section{Theoretical Framework}

This study adopts George Gerbner's Cultivation theory in carrying out research. The cultivation theory discusses the impact the television viewing makes on people on how they view the society. The theory states that:

The world of television drama is a mixture of truth and falsehood, of accuracy and distortion. It is not the true world but an extension of the standardized images which we have been taught since childhood. Cultivation analysis...inquiries into the assumptions television cultivates about the facts, norms, and values of society. $(179-182)$ 
The cultivation theory deliberates on the impact of continuous exposure to television and how it stereotypes the behaviour of the child, Gerbner initiated this theory as a result of his observation on the changes of attitude of people when they are constantly exposed to a particular type of attitude for a good number of times. Ozer Omer sees the cultivation theory as a random and "unintentional learning; unconscious gaining of demographic realities of the television world to the viewer. In other words, the concept explains the contribution of television watching to global perception and social reality conceptualization of the viewer" (188).Cultivation theorists such as George Gerbner and Larry Gross believe that television can create and maintain very basic set of beliefs about the world and that these influences are cumulative and long-lived ones. This indicates that the world view of a child who watches violence on the television does not change immediately, it is cumulative. Miller continues and states that:

Cultivation theory talks about the long term and cumulative consequences of exposure on an essentially repetitive and stable system of message which do not happen immediately but is gradual, stable and continuous. (27)

Children who spend more hours seeing film contents with negative portrayal of their society soon learn not to trust anyone in their environment and they also learn to react aggressively to certain situations. Children are often influenced the most, therefore, whatever they are exposed to at this stage of their lives needs to be looked into. Hence Nollywood children's films become the paradigms for this research. The above theory is evaluated in the course of this study as it highlights behavioural changes as regards to children through what they see or learn from film environment. 


\section{Leaders of Tomorrow and the Influence of Learning Materials}

The antecedent surrounding a child's upbringing determines how the child takes up responsibility when he grows up. Over the years, researchers and scholars have created and developed different methods and approaches detailing child development and the impacts of different learning techniques on the child's improvement. Some of the approaches are, Creative Dramatics, Theatre-in-Education (TIE), Role-playing techniques, Folklore, the Impact of Learning Environment, among others. Nevertheless, one may argue that the above methods have not been properly integrated into the school curriculum designed for teaching in most children schools in Nigeria. Each of the above mentioned methods of teaching or enhancing cognitive development of a child has its pros and cons, and each requiring a teacher, a facilitator, a guardian to see to its logical conclusion. However, in Nigeria today, the aforementioned methods are more or less not used effectively and the proliferation of contents of a new medium (Film) of acquiring knowledge which does not in most cases 'require' a facilitator, a teacher, or a guardian has emerged and some Nigerian children needing no permission from teachers or parents have grasped the opportunity and thus gradually, they have become their own teachers, guardians and facilitators in front of a television set. What they see, they interpret the way they deem fit and subsequently apply same in their dealings with their immediate environment. According to Uzoma Onyekwelu, Ifeyinwa Udegbe, and M. N. Ike,

Education has changed drastically over the last few decades in Nigeria. Many of these changes have been taken place at a time when we have been experiencing social changes which is concomitant with technological advances. In all these changes, nothing has been more significant and 
fundamental as modifications made in curriculum (Learning Environment). However, for effective transmission of what is worthwhile to youths... (Education) there must be an effective or meaningful learning. Learning which is change in the learner's behaviour (Overt or covert) (2)

An examination of the Nigerian society, discloses the challenges which the country's cultural system and leadership face. Daily, the nation's moral rectitude and cultural values are being attacked by some western ideologies and cultures, projected to the Nigerian audience through films. Many scholars agreed that there is a relationship between the appreciation of cultural norms, values and the education of a child. A look at the use of folklore for example allows the child to learn about historical artifacts and cultural values, and leadership positions of his people and he also tends to implement this knowledge in the later part of his life. Gbenga Rotimi opines that:

Folklore can simply be referred to as a particular tradition that belongs to a given people within a geographical area. This tradition is usually differentiated from other traditions through tangible cultural values as exhibited in oral histories, folklores, legends, myths, beliefs, fables and proverbs. Folklore is a natural source of materials for storytelling and drama. (37)

Some Nigerian parents no longer tell their children stories after school hours to exert the functions of folkloric tradition listed above (which are suitable elements in shaping the leadership skill of a Nigerian child) and Nollywood filmmakers are yet to incorporate the use of such traditions in their stories for the benefit of the Nigerian child. It is expected that parents especially those 
living in the cities should educate their children about their culture and values through folkloric stories and songs.

On the other hand, the film medium forms an enormous part of children's lives. Those who have the interest of childrenat heart agree that the extensive exposure of film has a profound influence on children, both positive and negative impact. For instance, Villani Susan emphasises that:

Excessive media use, particularly where the content is violent, gender-stereotyped, sexually explicit, drug or alcohol-influenced, or filled with human tragedy, skews the child's worldview, increases high-risk behaviours, and alters his/her capacity for successful, sustained human relationships. (395)

The above remarks suggest that a new form of film genre that will not be harmful to children is needed to navigate child's imitation of negative behaviours. In his contribution to scholarships on children films in Nollywood film industry, Bolu Folayan opines that:

Children films should be rooted in indigenous culture and indigenous media such as drama, theatre, folk, plays, poems, songs and proverbs should be employed in producing such films. Violence is not the only problem concerning children and the motion picture; hence national culture and values must be projected. (9)

Nigerians indigenous folklores, plays, theatre, poems, songs and proverbs one may argue are yet to be transported into Nollywood children film narratives. As such, the challenges of development facing African children in general and Nigerian children in particular as they strive to attend adulthood are enormous. 


\section{Film Content: An evaluation of leadership Skills in Nollywood Children Stories}

The crust of this research is to look at the content of children films produced in Nollywood industry and critically evaluates the film narratives (Stories) to see if they are inspiring stories that could influence children positively and help them adopt better leadership skills and become good leaders of Nigerian's tomorrow.

What are the contents of children's films? A children's film, could also be seen as a family film, which is a film category that contains children or relates to them in the context of home and family. One may say that children's films stories are designed and made specifically for them and not necessarily for the general audience, nevertheless there is a striking dissimilarity between Children film and family film because while family films are made for a wider appeal with a general audience in mind, Children's films come in some foremost forms like realism, fantasy, adventure, animation, musicals, and literary adaptations. Most characters portrayed in the above stories or forms, assume leadership positions at some point in the stories. In interrogating the above genres and subgenres, how children respond to certain issues and take responsibilities are examined. Possible lessons that may be derived from such films, their developmental impacts on the young audience, and their educational values to the children are put into cognizance in designing the genres. With the above definition in mind, it becomes difficult to define Nollywood children Film contents and if the stories are embellished with enough artistic ornaments to propel good leadership skills in the young audience. However, this study sees Nollywood children contents as films produced for the children, from the perspective of children, detailing their relevant roles in the family in particular and in the society at large as well 
as inculcating in them positive, moral rectitude which would enhance their understanding of good leadership skills and good character formation. A look at some Nollywood children films' contents would help in buttressing the fact if any in the above definition.

1. Jack and Jill published online (YouTube) in 2015, is Nollywood children film that talks about two children, Jack and Jill whose wicked uncle brings into his home to help them stay "positive" in an immoral society full of immoral acts. But instead of giving positive advice to the children, he tries to influence them negatively. Their uncle gives them instructions in the following lines. Uncle: "You must clean the toilet every morning, no boyfriend and no girlfriend in my house, no police case, you must change your atrocious names to Jack and Jill." Jack: "Okay, what if babe come see us or to bring money to give us?" Uncle: "Find work, even those who do pick pocket they are making good money."'The above conversation shows a narrative done from adult's perspective, their uncle knows more about the city, he knows the trending events in his immediate environment but the children are ignorant of some of the events, such as pick pocketing. One may say that the narrative above shows how some adults in the society debilitate and poison the young minds and indoctrinate them into their world of mischief. The children who grew up with such mentality may not become good leaders of tomorrow. In further reading of the film, the children become notorious in the society and nightmares to their parents. The content of the above film places children at par with adult audience who have the ability to sieve, dissect and evaluate every situation in life and in most cases make the right decisions. The child's brain is malleable, and 
as such, takes in information that is readily available without evaluating the outcome of his or her actions.

2. Cain and Abel published on YouTube in 2015 is another story of two children who are in enmity with each other. The children (Williams and Junior) are also neighbours, each with a single parent, William lives with his Father while Junior lives with his mother. The opening scene establishes the children in their different homes. William goes out of the house after been scolded by his father. Williams's Father: "Williams come back here" Williams: (Climbs a tree in the compound) Hmmmm!" Williams's Father: "Okay, I am going to cut your supply of biscuits, sweets,"Next scene introduces Junior and his mother. Junior walks out on his mother angrily,

Junior's Mother: "You do not walk out on your mother (Junior comes back crawls on the floor) you do not crawl out on your mother. (Junior comes back rolls on the floor) You do not roll out on your mother. (Junior comes back and sits down)"

The above happenings showcase Williams and Junior as stubborn children and the next happenings buttress the assumption. Williams monitors his father's relationship with their female neighbour (Junior's Mother) and interrogates his father who is seen cleaning the dining table and the father tells him, he is expecting a visitor and that's why he is cleaning everywhere in the house. After cleaning, he goes into the bathroom to take his bath and the visitor arrives. The following dialogue takes place between William and the visitor. Junior's Mother: "Is your father in?" Williams: "Yes, but he is not expecting you" (He slams the door on the woman's face and she leaves angrily) 
The film message is propagated through Williams and Junior as two children who because of their own personal aggrandizement do not want their parents to come together as husband and wife.

Williams and Junior pour out their anger in the following conversation, Junior: "Monkey, you tell your father to stop running around my mother." Williams: "You Chimpanzee, tell your shameless mother to stop begging my father, have you heard? And tell her to stop coming around to give my father cake. If I see her next time in my house, I will kill her" Junior: "See if I catch your father again coming to our house naked, I will put him into our wardrobe and lock him up"

The little excerpt above overlooks a lasting spell that could daunt good behaviours of the young audiences who see the film. And believing that children should be the watchdog of their parents, monitoring their excessive excesses in marital affairs, one may suggest that children can be more relevance to their parents other than being gossip mongers and mischief conveyors as witnessed in the film Cain and Able. Children who did not grow up with love are not likely to dispense it. A good leader loves his or her subjects. Putting into practice the theory of cultivation by George Garbner, the above film's narrative teaches children enmity and this could in a long run influence the way they see their fellow human beings, and if eventually some children with the above orientation found themselves in leadership positions, they may not lead their people with selflessness, love and compassion, hence gradually they have cultivated bad tenets, behaviour, and negative influences seen in movies into their belief system. One may say without any iota of doubt, that Nigerian leaders are lacking the above virtues (Love, selflessness and compassion) in dispensing good governance to Nigerians. Nollywood children 
films' narratives could change such acrimonious leadership positions and teach Nigerian children how to care and love.

3. Obama - The Postmaster (2017, also available on YouTube) is a Nollywood film that details young children's activities in the classroom (Primary School). The protagonist, Obama (Osita Iheme) is a boy whose shrewdness overshadows that of his classmates and outwits his teachers as well. Obama is the only son of his parents, as such, as it is in some African cultures much eccentricities are accorded to him. He enjoys a lot of privileges which in turn puts him as "superman" who does whatever he wishes, when he wants it and wherever he wants and to whomever he wants to intimidate. He changes the name his parents gave him, and adopted the name of an iconic terrorist Osama. He terrorises the elders in his community, his teachers in the classroom, his classmates as well as his father. And instructs his classmates to address him as Osama the terrorist. In one of his expeditions, he goes to the lady's convenience to ask his female teacher a question that should have been addressed and answered in classroom. He did so just to get a glimpse of his teacher's nakedness. Such escapade exposes other children who are not well trained to adopt ill-mannered way of life as exemplified in the film. This is so, hence one may say that everybody wants to be a "superman" and children are more vulnerable when it comes to having such desires and this is why most of them act out the roles of superheroes they have seen in movies examples are, Batman, Superman, Spiderman, Shina Rambo, among others. Parents providing their children with all they want as exemplified in the above film has contributed in no small measure to the extravagant life style they adopt when they attain adulthood. Delayed gratification has no place in some parents' 'dictionary'. A child who finds it difficult to understand 
that events happen for reasons may find it difficult becoming a good leader of tomorrow. Because while growing up everything he ever wanted was provided by his parents without any delay. If he finds himself in government, one is not expecting such person to do otherwise. The actions exhibited by the character Osama, were channelled negatively and this is where some filmmakers get it wrong, an intelligent character should be good because the imitation of his actions are inevitable especially to the young audience. One may say without any shade of doubt that if the above contents are what Nigerian children see often in movies, the society may be doomed in making any innovative progress.

4. Mafian Kids: Showing a different narrative content from the above narrations, the movie Mafian Kids (2015) directed by Chimdi Chiama presents families that play and pray with their kids. This film captures succinctly a certain happy family and their struggles to come to terms with their marital problems caused by a lingering rancour from a previous relationships and how the children cope in such situation becomes part of the film narrative.

Mary (Regina Daniel) and her two little brothers Nnamdi and Chinonso have a lovely family that prays together and stays together. The parents of the kids also understand the need to exclude children from "adult discussion" This happens when the wife (The kids' Mother) realizes that her husband Tony (The kids' father) cheats on her with another lady named Favour. When the argument between Mary's parents is about to heat up, the mother talks to her kids. Mother: "Mary take your brothers into the room." This act shows that the film makers understand the place of the children in a family setting. Mafian Kids is exceptional, fascinating and didactic as it relates to family issues. In another instance, the parents talk with their children, asking them questions of what they 
would like to be when they grow up. Father: Mary, tell us what would you like to be when you grow up? Mary: "I would like to be a Reverend Sister." Mother: "What of you Nnamdi?" Nnamdi: "I like to be a soldier." Father: "A soldier, that's great, what of you Chinonso?" Chinonso: "I want to be a lawyer".

In another scene, the children are asked questions of what they learn in school, questions the children answered brilliantly. Their school teacher visits their home any day that any of the kids did not come to school thereby showing concern and commitment to the wellbeing of the school kids. Many parents and teachers neglect this part of child's upbringing of constantly checking the kids' academic performances. Most children are brilliant, they are sensible of many things happening within their immediate environment and the kids in the film under discussion are not exception. They became aware of their parents' squabbles eventually, and the infidelity of their father and what do they do? They prayed for their parents' unity until God almighty answered their prayers and through their prayers one may say, their parents overcame their marital issues. This act portrayed a clear departure from what one witnessed in the other film Cain and Able where the kids are more or less "destructive agents" nightmare of their parents. The film narrative shows parents who love their children and children who love their parents. And if children who saw this film through the theory of cultivation could imbibe such love as they grow into adolescence and adulthood, they would make good leaders of tomorrow wherever they found themselves in human endeavours.

5. Tom and Jerry: Divine Touch Productions brings another film with children content entitled Tom and Jerry published online (YouTube) in 2017. Tom and Jerry is a Nollywood children film 
that tackles the issue of an extended families. The two impetuous brothers (Tom and Jerry) are detested due to their dire nature. Tom and Jerry live with their blind grandfather in the village. In this film, one sees a grandfather who needs all the help he can get from people around him, especially from his two grandchildren but unfortunately for him, the children who now found themselves in leadership position become his greatest nightmare. The children accord no respect to their grandfather or even to their grandfather's friend Adindu. As they walk their blind grandfather along the road, they misdirect his steps by taking away the blind man's walking stick causing him to fall on the ground and the Old man laments. "Only God knows where these children came from. Who knows where they would end up? You are going to face the firing squad" Tom and Jerry keep late hours, come back to the house whenever they like. In one of the instances, their grandfather locks them out. And as such, they ordered their grandfather to open the door. Tom says "Papa $P$, we are going to break this door. If we sleep outside now and cold enter my body. Remember we are your children." And Papa P's reply is direct "Chukwunna o ga-ekweka m mutaumu di kaunu. (God forbid me fathering children like you two)" One may say that Papa P's action did not portray love and good leadership examples to the children but this is a blind man who has no other help in his house apart from himself as later revealed in the film. Papa $\mathrm{P}$ goes further to castigate his grandchildren "Sons of the devil, sons of Satan, idiots, wicked children. You don't do any work in this house. Are you not supposed to be washing my clothes for me? Useless children" The children steal money from Adindu, throw stones at their fellow children at the village stream, steal their grandfather's pot of soup while the blind man is cooking the soup, they commit all sorts of atrocious acts. They torment the whole village with their tricks and wreck every home and 
restaurant. In one of their crime escapades, they pour powdered pepper in their grandfather's snuff and the old man nearly died after snuffling it. And as if that was not enough they go to Adindu's house and beg him to help them reconcile with their grandfather, a task Adindu carries out without knowing the hidden intention of the kids. The kids discuss their next line of action. Jerry: "We will use him and make money when we make peace with him" Tom: "How?" Jerry: "Have you not seen people's reaction towards blind people?" Tom and Jerry deceive their grandfather, telling him that they are taking him to see a nurse who would see to his wound, having made peace with them, he follows them without suspecting any foul play. The kids use their blind grandfather as a beggar on the streets and at the village market before he realises what they were doing. And he curses them in the following lines "I invoke Amadioha twenty times to struck these children who call themselves my grandchildren" A curse one may say did not come through in the end of the film. It is appalling that the children characters (actors) are equipped with so many distasteful behaviours when it should be the opposite. The main children characters in the film are mischievous, nonchalant and disobedient to their elders. One may also say that their grandfather did not show them the needed care and love hence locking them out of the house in the night is a childish display and uncalled for. Andindu admonishes him "Papa P, You shouldn't have done that, Children will always be children" The above statement also does not stipulate the adequate punishment that should be melted out on a child who has erred, an erring child deserved to be cautioned with the appropriate measure so as to direct his or her vision towards a positive one. Having observed the above film contents, analysing its possible influence on the Nigerian children shows that tomorrow is going to be disconsolate for the leaders of 
tomorrow if the film narratives are not changed. The examples from most of the films' contents analysed above are bad examples that through the process of cultivation theory, the child audience's behaviour after watching the films may not tilt towards positive influence about leadership roles because virtually, the children characters abuse the opportunity given to them to be good examples to others with the exception of the Mafian Kids.

\section{Conclusion}

Lessons derived from the above films are numerous, hinging on Garbner's cultivation theory, children learn norms, rules, nonchalant attitudes, disobedient, robbery, cheating, distrust, love, hatred among other vices. Most of the children characters' lines (words) and thoughts are not believable to be that of children in the society. Inadvertently, the filmmakers are equipping the child audience with such abhorrent vices. The manners in which the children characters carry out their exploits are questionable; one may say that the children characters created in the above films are living in the world of 'mischievous adults'. The way they fashion out lies, construe nonchalant behaviours, meddle with the adult issues (As exemplified in Cain and Abel) calls for a serious restructuring of the children narrative in Nollywood Film Industry. If the children are really leaders of tomorrow, then, how Nollywood shape their ideas, interests, and their worldview is very important so as to imbibe and cultivate in them the spirit of hard work, love of one's neighbour, technological advanced world whereby they could start on time to think and cultivate the leadership skills in the area of technological innovation, inventions and construction as witnessed in most Hollywood children films, good examples of such films are Spy Kids, Harry Potter and the order of the Phoenix (2007), Harry Potter: The 
Sorcerer's Stone (2005) Barbie in a Mermaid Tale (2010), Beasts of the Southern Wild (2012), Mud (2013), Maleficent, (2014), Akeelah and the Bee (2006) among others.

\section{Recommendations}

$>$ Cultivation theory is a wonderful theory that showcases children as audio-visual learners who imbibe and inculcate in their minds whatever they are exposed to. So if Nigeria society wishes to change the way the "leaders of tomorrow" (Children) are brought up, Nollywood Film Industry could be a suitable channel to propagate an ideal leadership skill for the young.

$>$ The researcher therefore recommends, establishment of a film unit that should provide adequate censorship of children films. The unit should be empowered to sieve, dissect and scrutinize all children film contents in Nollywood Film Industry so as to make sure that the filmmakers produce films relevance to the academic and character formation needs of Nigerian children. Hence, children are the leaders of tomorrow.

$>$ Children as continual members of society's future need to be taught the right way of existence, how to take care of the old, how to contribute to the wellbeing of their families and society and so on and so forth. Nollywood filmmakers should as a matter of urgency, include positive attitude portrayals in children films' characters so as to achieve a sustainable future for Nigerian children as well as to Nigeria society.

$>$ Nigeria Video and Film Censorship Board should be saddled with the responsibility of organizing workshops, conferences and symposia in order to train and retrain moviemakers in Nigeria with regards to children film productions. 


\section{Nkemakonam Aniukwu (PhD) \\ Theatre and Film Studies \\ Nnamdi Azikiwe University, Awka nj.aniukwu@unizik.edu.ng}

\section{Works Cited}

Akoh, Ameh. "Oral Performance and the Ibaji-Igala Society in Transition: The Songs of Oyaka Contextualized." Applause: Journal of Theatre and Media Studies 1.2 (2006): 109-127.

Cain and Abel. Dir. Uzo Philips Amayo. Perf. Osita Iheme Chinedu Ikedieze. 2003. YouTube. 10 January 2019.

Finnegan, Ruth. Oral Literature in Africa. Vol. 1. Cambridge: OpenBook Publishers, 2012. PDF. 22 October 2017.

Folayan, Bolu. "Can Nollywood Save Nigerian Children from an Impending Mass Society?" Covenant Journal of Communication 3 .2 (2016): 1-13. PDF. 21 August 2019.

Gbenga, Rotimi. "Folklore as a Source of Material for Educational Theatre in Secondary Schools for Cultural Reconstruction." Theatre, Creativity and Democratic Practice in Nigeria. Ed. Amen Akoh, Abdulrasheed Adeoye and Ezenwanebe Osita. Lagos: Society of Nigeria Theatre Artists, 2014. 3546. PDF. 30 July 2018. <researchgate.net>.

Gerbner, George. "Scenario for Violence." Human Behavior,

October

http//:www.georgegerbner/communicationtheory.com PDF. 30 June 2019.

Gerbner, George. And Larry Gross. "Living With Television: The Violence Profile" Journal of Communication June. 1976DOI: 10.1111/j.1460-2466.1976.tb01397. 172-199. PDF. 30 June 2019. 
Jack and Jill. Dir. Kalu Anya. Perf. Chinedu Ikedieze, Osita Iheme. 2011. YouTube. 29 June 2018.

Mafian Kids. Dir. Chimdi Chiama. Perf. Evelyn Ese, Regina Daniel. Rising Sun Production. 2015. YouTube. 10 June 2018.

Miller, K. Communication Theories: Perspective, Process and Contest. Boston : McGraw Hill, 2002.

Nwosu, Canice. "The Changing Nigeria Family and the Rights of the Child in Bassey Ubong's Freeworld Square." Applause: Journal of Theatre and Media Studies (2006): 31-49.

Obama-The Postmaster. Dir. Andy Chukwu. Perf. Osita Iheme. 2017. YouTube. 29 June 2018.

Onyekwelu, Uzoma, IfeyinwaUdegbe, M. N. Ike. "The Impact of Good Learning Environment Academic Achievement and Retention of Primary Four Pupils" World Educators Forum. ttp://www.googlescholarsearchchildrenandlearning. Accessed on $13^{\text {th }}$ August, 2018

Ozer, Omer. "Cultivation Theory and Hegemony: A research from Turkey on Cultivational Role of Television" Informatologia. 2011. 187-192, PDF https//:hrcak.hr/72599.comAccessed on $13^{\text {th }}$ August, 2017.

Tom and Jerry. Dir. Kenneth Egbuna. Perf. Osita Iheme, Ada Ameh, Chinedu Ikedieze. Prod. Kingsley Okereke. 2008. YouTube. 20 December 2018.

UNICEF. The Convention on the Rights of the Child. 20th November 1989. Online (PDF). 10th March 2019.

Villani, Susan. "Impact of Media on Children and Adolescents: A 10-Year Review of the Research." Journal of American Academy of Child and Adolescent Psychiatry, 40.4 (2001): 392-401. $\quad$ PDF. $30 \quad$ July 2019. <http://www.mediaimpactsusanv....googlescholar.com>. 